\title{
Article
}

\section{Analyses of the Updated "Animal rDNA Loci Database" with an Emphasis on Its New Features}

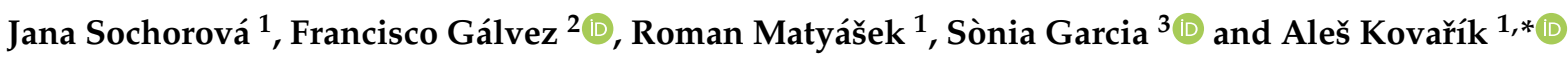 \\ 1 Institute of Biophysics, Academy of Sciences of the Czech Republic, 61265 Brno, Czech Republic; \\ sochorova@ibp.cz (J.S.); matyasek@ibp.cz (R.M.) \\ 2 Bioscripts-Centro de Investigación y Desarrollo de Recursos Científicos, 41012 Sevilla, Spain; \\ franciscogp@bioscriptsdb.com \\ 3 Institut Botànic de Barcelona (IBB-CSIC), Passeig del Migdia s/n, 08038 Barcelona, Spain; \\ soniagarcia@ibb.csic.es \\ * Correspondence: kovarik@ibp.cz
}

Citation: Sochorová, J.; Gálvez, F.; Matyášek, R.; Garcia, S.; Kovařík, A Analyses of the Updated "Animal rDNA Loci Database" with an Emphasis on Its New Features. Int. J. Mol. Sci. 2021, 22, 11403. https:// doi.org/10.3390/ijms222111403

Academic Editor: Hikmet Budak

Received: 17 September 2021

Accepted: 20 October 2021

Published: 22 October 202

Publisher's Note: MDPI stays neutra with regard to jurisdictional claims in published maps and institutional affiliations.

Copyright: (c) 2021 by the authors. Licensee MDPI, Basel, Switzerland. This article is an open access article distributed under the terms and conditions of the Creative Commons Attribution (CC BY) license (https:// creativecommons.org/licenses/by/ $4.0 /)$
Abstract: We report on a major update to the animal rDNA loci database, which now contains cytogenetic information for $45 \mathrm{~S}$ and $5 \mathrm{~S}$ rDNA loci in more than 2600 and 1000 species, respectively. The data analyses show the following: (i) A high variability in $5 \mathrm{~S}$ and $45 \mathrm{~S}$ loci numbers, with both showing 50-fold or higher variability. However, karyotypes with an extremely high number of loci were rare, and medians generally converged to two $5 \mathrm{~S}$ sites and two 45S rDNA sites per diploid genome. No relationship was observed between the number of $5 \mathrm{~S}$ and $45 \mathrm{~S}$ loci. (ii) The position of $45 \mathrm{~S}$ rDNA on sex chromosomes was relatively frequent in some groups, particularly in arthropods (14\% of karyotypes). Furthermore, $45 \mathrm{~S}$ rDNA was almost exclusively located in microchromosomes when these were present (in birds and reptiles). (iii) The proportion of active NORs (positively stained with silver staining methods) progressively decreased with an increasing number of $45 \mathrm{~S}$ rDNA loci, and karyotypes with more than 12 loci showed, on average, less than $40 \%$ of active loci. In conclusion, the updated version of the database provides some new insights into the organization of rRNA genes in chromosomes. We expect that its updated content will be useful for taxonomists, comparative cytogeneticists, and evolutionary biologists.

Keywords: ribosomal DNA; rDNA; rRNA genes; nucleolar organizer regions; karyotype; sex chromosome; B chromosome; Ag-NOR; database; animals

\section{Introduction}

Ribosomal DNA (rDNA) loci encoding 5S and 45S (18S-5.8S-28S) rRNA genes are vital components of eukaryotic chromosomes [1]. Ribosomal DNA also plays a pivotal role in nuclear organization by assembling the nucleolus [2] and epigenetic stabilization of the genome [3]. Ribosomal DNA loci, together with centromeres and telomeres, are distinguished features in eukaryotic chromosomes. While telomeres and centromeres tend to occupy specific chromosome regions, rDNA loci are often found at variable positions and numbers. These features make rDNAs important karyotypic and phylogenetic markers. Although the relationship between nucleolar organizer regions (NOR) and distinct chromosome segments had already been proposed by Barbara McClintock [4], the composition of NORs and rDNA loci in general were only deciphered with the aid of in situ hybridization experiments in the 1970s [5-7]. However, the invention of fluorescence labeling of probes [8] triggered enormous progress in the molecular cytogenetics of rDNA loci. Currently, many protocols are available for fluorescence in situ hybridization (FISH) of rDNA in different systems [9-11]. Ribosomal DNA may occur at any place on chromosomes, whereas some preference exists for its subtelomeric position, at least in the case of $45 \mathrm{~S}$ rDNA; however, $5 \mathrm{~S}$ rDNA is more variable [12-14]. Aside from its standard position on autosomes, there are also examples of rDNA occurrences on sex chromosomes $[15,16]$ and 
B chromosomes $[17,18]$. In addition, rDNAs may even be largely pseudogenized in some large genomes $[19,20]$.

For many years, cytogenetic data on rDNA loci remained scattered across the literature or compiled into lists available only in hard copy. This motivated authors to generate public databases summarizing information about the number and position of rDNA loci in plants [21] and animals [13]. Here, we report on the first update of the animal rDNA loci database (http:/ / www.animalrdnadatabase.com), which went live in August 2021 and which collates data from 1040 original publications. In the analyses, we addressed questions on: (i) the diversity of rDNA loci numbers, (ii) the occurrence of rDNA loci in chromosomes with limited or no recombination capacity, and (iii) the relationship between $45 \mathrm{~S}$ rDNA loci numbers and their activity.

\section{Methods}

\subsection{Data Collection}

The database includes data collected from the literature until March 2021 (1040 papers). Papers were retrieved from the bibliographical databases Thomson Reuters WOS, MEDLINE/PubMed and Google Scholar. Queries used for search were: "rDNA", "rRNA", "chromosome", "in situ hybridization", "FISH", "hybridization", and all combinations thereof. We also searched in the references of each of the retrieved papers. The data come mostly from fluorescent in situ hybridization (FISH) experiments, although a small number of older entries were obtained from radioactive hybridization methods. The assessments of the number and position of rDNA signals were taken from the authors' evaluations when explicitly mentioned and manually counted when only shown in chromosome pictures.

New features for an advanced search were added, such as information about the type of chromosome-bearing rDNA locus (autosome, sex chromosome, and B chromosome) and information about the number of Ag-NOR signals (reporting active NORs detected by silver nitrate staining). Papers containing unclear information about the number of Ag-NOR signals or citing another research paper analyzing these data were disregarded. In the text, the terms "locus", "site", and "signal" are used interchangeably.

\subsection{Website Construction}

The tabular database structure comprising the rDNA and literature data was created in SQL (Structured Query Language) tables on a MySQL server. Each table had its own different field type and size. The initial spreadsheet table in which the data were compiled was exported to a CSV (comma-separated values) file. A unique ID was given to each entry, together with the date and time of the export and the version of the database. Then, it was imported (current version is the seventh import) into the SQL database (www.animalrdnadatabase.com). The website was programmed in HTML (HyperText Markup Language), CSS (Cascading Style Sheets), and JS (JavaScript) to visualize the website. The custom functions in PHP (PHP: Hypertext Preprocessor) were written to query the database and process and display the data.

\subsection{Data Analyses}

We carried out basic statistical analyses of the results (locus number average, median, range for all groups) using MS Excel and RStudio [22]. The Spearman's correlation coefficient (Rs) was counted using "RANK(AVG) and "CORREL" commands; values above 0.04 (in absolute values) were considered significant $(p<0.05)$. The statistical support for differences between the groups was calculated using the ANOVA (MS Excel function) and Mann-Whitney (online program: Mann_Whitney_U_test_calculator [23]) tests. The Levene's equality test (online program: [24]) was applied to determine the homogeneity of variances in locus numbers between the groups. We also analyzed rDNA locations on different types of chromosomes (autosomes, sex chromosomes, and B chromosomes) in the different groups of animal species. In box plot graphs (constructed in RStudio), 
values $<$ Q1 $-1.5 \times$ IQR and values $>$ Q3 + 1.5 $\times$ IQR are outliers (IQR computed as the interquartile range of the input data).

\section{Results and Discussion}

\subsection{Database Content}

Since its first release in 2016, the number of entries in the current version has almost doubled (Figure 1). The cytogenetic information about rDNA (either $45 \mathrm{~S}$ or $5 \mathrm{~S}$ ) is currently available for more than 2500 species (Table 1). The largest groups include arthropods (1068 karyotypes, 38\%) and fish (953 karyotypes, 34\%).

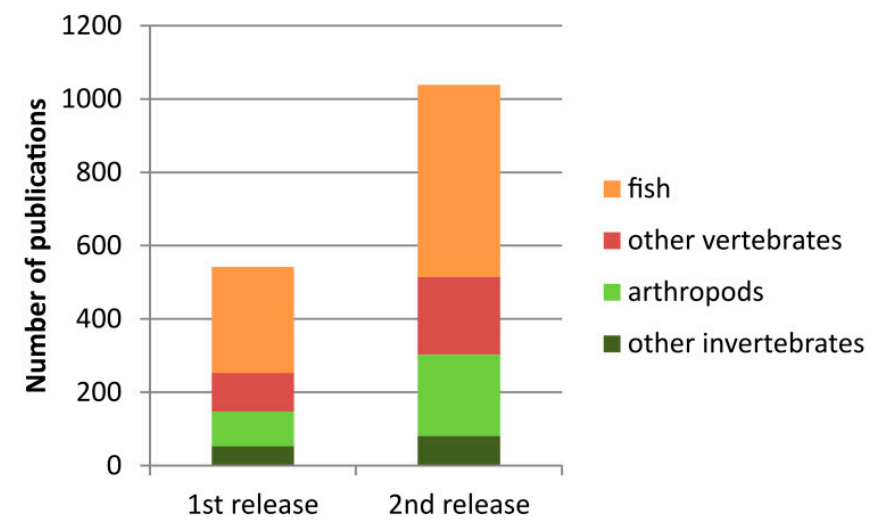

Figure 1. Increased amount of literature in the current version of the animal rDNA loci database.

Table 1. Amount of cytogenetic data for $5 S$ and $45 \mathrm{~S}$ rDNA loci in the database and their relationship to each group's diversity.

\begin{tabular}{|c|c|c|c|c|c|}
\hline Group & $\begin{array}{c}\text { Group } \\
\text { Diversity }\end{array}$ & rDNA locus & $\begin{array}{l}\text { Number of } \\
\text { Karyotypes }\end{array}$ & $\begin{array}{l}\text { Number of } \\
\text { Species }\end{array}$ & Species Repr. [\%] ${ }^{2}$ \\
\hline \multirow{2}{*}{ Invertebrates } & \multirow{2}{*}{$\sim 1.5 \times 10^{6}$} & $5 S$ & 174 & 174 & 0.01 \\
\hline & & $45 S$ & 1173 & 1149 & 0.08 \\
\hline \multirow{2}{*}{ Vertebrates } & \multirow{2}{*}{$\sim 7.3 \times 10^{4}$} & $5 S$ & 897 & 880 & 1.21 \\
\hline & & $45 S$ & 1557 & 1526 & 2.09 \\
\hline \multirow{2}{*}{ Total } & \multirow{2}{*}{$\sim 1.6 \times 10^{6}$} & $5 S$ & 1071 & 1054 & 0.07 \\
\hline & & $45 S$ & 2730 & 2675 & 0.17 \\
\hline
\end{tabular}

${ }^{1}$ Number of species in the group. Source: IUCN [25]. ${ }^{2}$ Percentages are counted as number of species/group diversity.

The remainder, including mammals, amphibians, birds, mollusks, and reptiles, among others, represents $28 \%$ of the database content (796 karyotypes). Although birds are the second largest class of vertebrates (after fish), they were severely underrepresented in a previous release. The current release has improved the situation in that it contains data for 83 bird species, mainly collected from a recent publication of Degrandi et al. [26]. Arthropods seem to be well represented in the database, but considering that they are the largest animal group ( $>1.3$ million species, about $95 \%$ of all animals, source: [25,27]), their representation is relatively low $(<0.1 \%$ species $)$. It is, therefore, not surprising that the data for arthropods are steadily expanding. For example, Stahlavsky et al. [28] recently published FISH data on $18 \mathrm{~S}$ rDNA loci for 74 scorpion species, which were not represented in the previous release. The best represented group in terms of diversity is fish, which also has relatively balanced entries for both $45 \mathrm{~S}$ and $5 \mathrm{~S}$ loci (Table S1). Considering animal diversity (Table 1), our information about rDNA loci is still fragmentary, but a continuous rise in publications can be envisaged.

\subsection{The Number of rDNA Loci Is Variable, but Most Species Tend to Maintain a Low Locus} Number

The number of rDNA loci is an important characteristic of every karyotype. This can be relatively easily determined by counting the probe hybridization signals in metaphase 
chromosomes, although this depends greatly on the chromosome size and the quality of materials for the analysis. Figure 2 shows the distribution of locus numbers in individual groups. In all major groups that could be statistically evaluated (those represented by at least 40 karyotypes), the medians ranged from two to three sites (both $5 \mathrm{~S}$ and $45 \mathrm{~S}$ ) per diploid karyotype (Table S1).

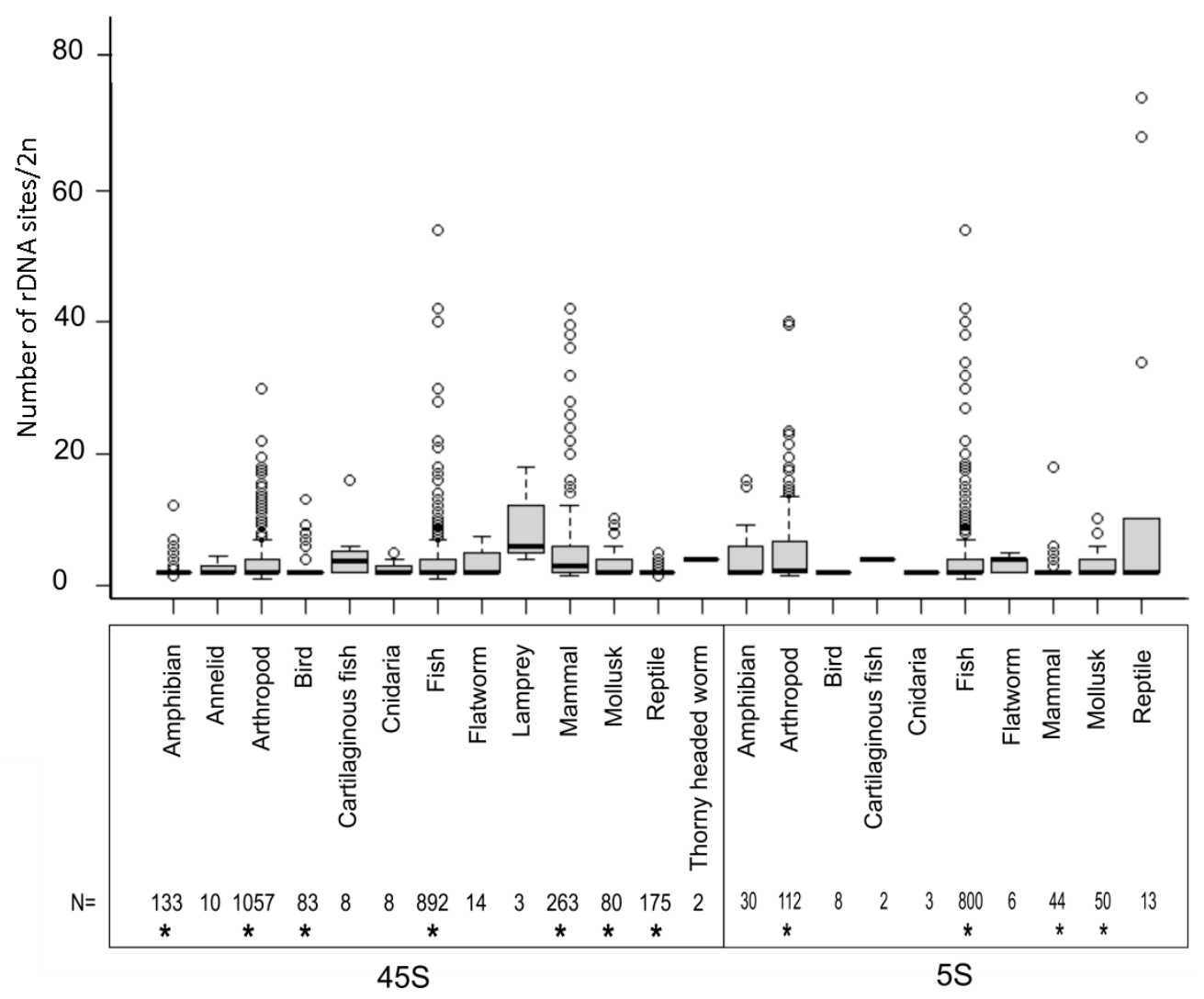

Figure 2. Number of $45 \mathrm{~S}$ and $5 \mathrm{~S}$ rDNA sites per diploid cell in different animal groups. The sample size is shown below the diagram. Boxes represent Q1, median, Q3. Outliers marked by circles were calculated from the interquartile range (IQR): < Q1-1.5 $\times$ IQR and $>$ Q3 + $1.5 \times$ IQR. Asterisks $\left(^{*}\right)$ below the numbers mark groups in which statistical tests were carried out (Table S1).

It is, therefore, not surprising that in many genera karyotypes with two NORs (per diploid genome), this has been considered the ancestral condition [29,30]. Mammals had a slightly larger number (5.51 average; 3.0 median) of $45 \mathrm{~S}$ loci compared to other animals $(p<0.05$, Mann-Whitney $\mathrm{U}$ test, Table S2). The largest number of $5 \mathrm{~S}$ loci was observed in arthropods (6.46 average; 2.25 median; $p<0.05$, Mann-Whitney U test). However, in each major group, prominent outliers were observed, with a locus number significantly deviating from the average. The number of $45 \mathrm{~S}$ loci (per 2C) ranged 1-54 in fish (892 karyotypes), 1-42 in mammals (263), 1-30 in arthropods (1057), 2-13 in birds (83), 1-12 in amphibians (133), 2-9 in mollusks, and 1-7 in reptiles (175) among the most ( $>50$ species) represented groups (Table S1). The $5 \mathrm{~S}$ loci ranged 1-54 in fish (800 karyotypes), 1-40 in arthropods (112), 2-18 in mammals (44), and 2-10 in mollusks (50). About $2.5 \%$ of karyotypes harbored a single rDNA site per diploid set, mostly occurring in heterogametic species bearing a single locus on sex chromosomes and none on the autosomes (specifically, $0.46 \%$ for $5 \mathrm{~S}$ and $2.01 \%$ for $45 \mathrm{~S}$ loci). Two large groups (arthropods and fish) showed near equal variability in the number of $45 \mathrm{~S}$ rDNA sites (Levene's test, $p>0.05$ (Table S3)), suggesting that differences between groups tend to diminish as the sample size increases and that a group's diversity is likely the main factor influencing locus number variability. Remarkably, a several-fold variation in locus number was observed at the genus level in groups as phylogenetically divergent as grasshoppers [31] or mice [32]. Although the time 
scales of these shifts are unknown, they demonstrate the overall well-known dynamics of rDNA in chromosomes $[13,33,34]$.

There was weak to no correlation between the number of rDNA loci and chromosome number (Figure 3A,B and statistical tests (Table S4)). This apparently holds true even for species with an extremely large (typically $>160 / 2 C$ ) number of chromosomes, such as lampreys [35-37], some arthropods (e.g., the Austropotamobius genus members [38]), and some fish (e.g., Acipenser [39]), which tend to keep their rDNA locus (45S) numbers close to the median (low).

A
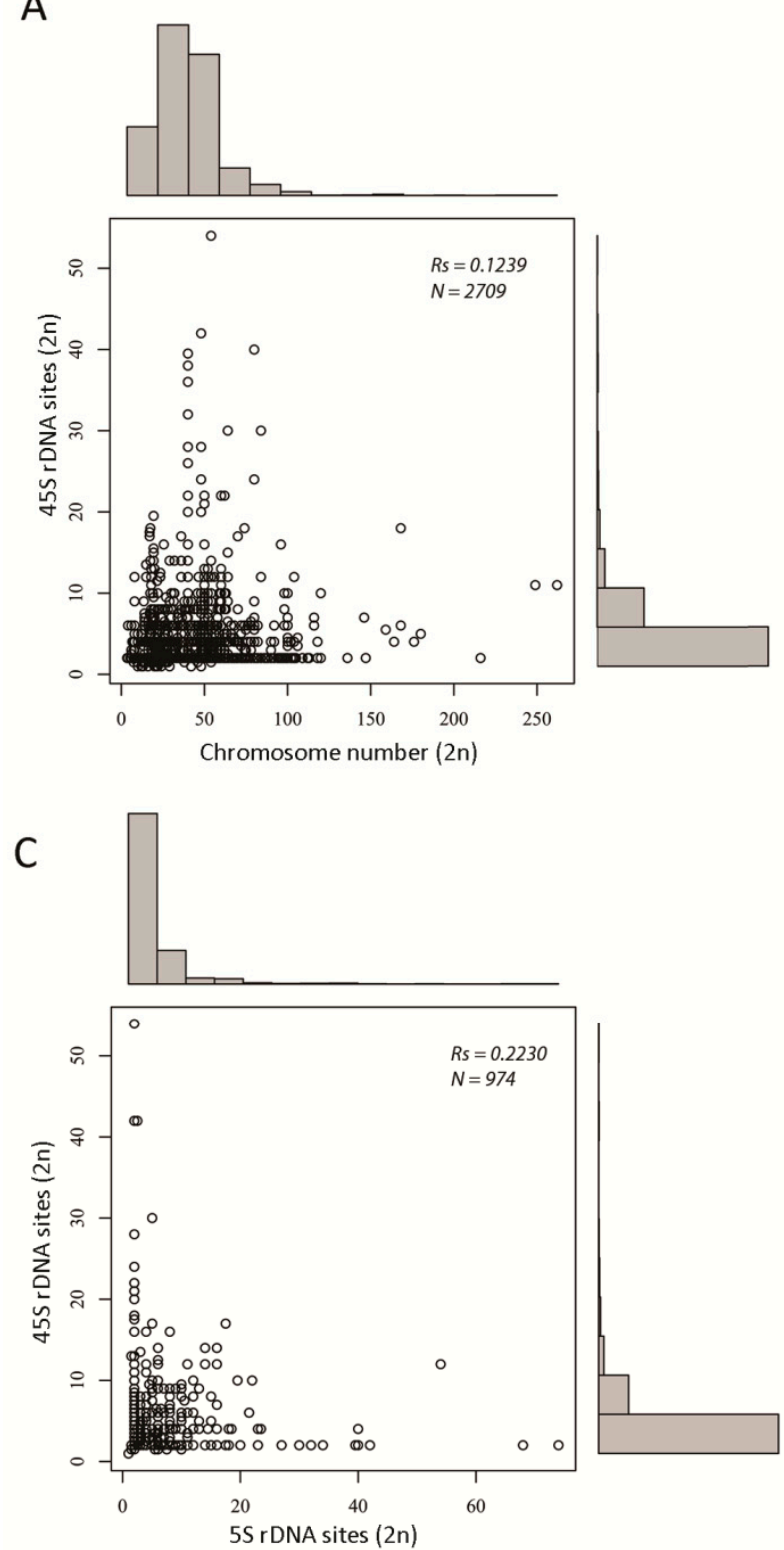

B
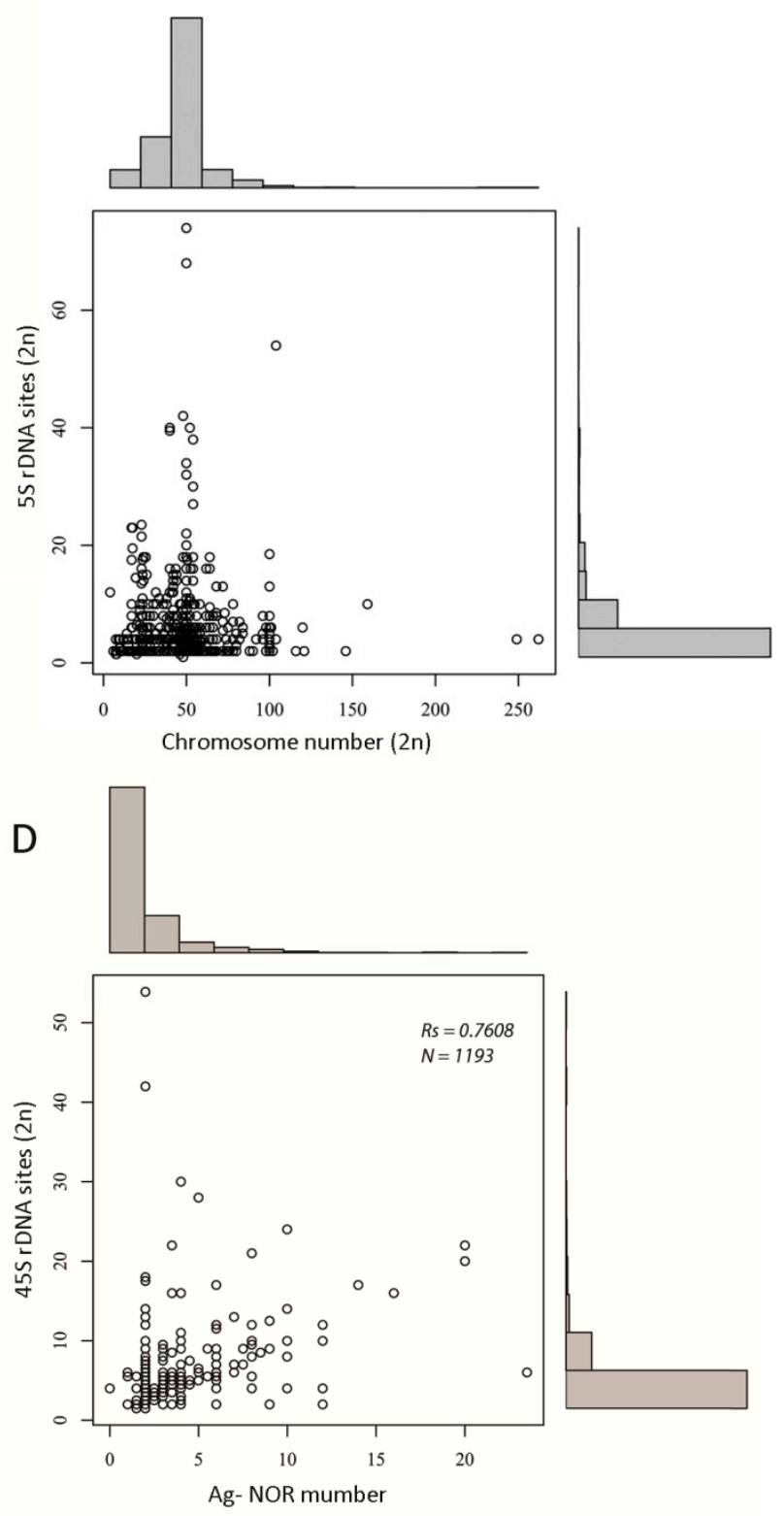

Figure 3. Scatter graphs showing relationships between rDNA locus number and other variables including chromosome number and number of Ag-NOR signals. (A) A plot of $45 \mathrm{~S}$ rDNA and chromosome number. (B) The same as in (A) but for $5 S$ rDNA. (C) A plot of $5 S$ and $45 S$ rDNA numbers. (D) A plot of the number of Ag-NOR signals and number of 45S rDNA loci. Legend: Rs, Spearman's correlation coefficient; N, number of data points. Details of statistical tests are in Table S2.

There was a weak correlation between the number of 5S and 45S loci (Spearman's Rs $=0.22, \mathrm{~N}=974$ (Figure 3C and Table S4)), which is in line with our previous study using about half of the amount of data [13]. Additionally, both parameters were not correlated at the group level, for instance in arthropods $(\mathrm{Rs}=0.03)$ and fish $(\mathrm{Rs}<0.01)$. Strikingly, a similarly weak correlation (Spearman's Rs $=0.24$ ) was observed between $18 \mathrm{~S}$ and $5 \mathrm{~S}$ 
copy numbers in human populations [40], indicating independent evolution of these loci, in general. This, however, does not exclude common shifts at the population level [41].

\subsection{The Occurrence of rDNA Loci on Sex and B Chromosomes}

The new database option allows the retrieval of information about the presence/absence of sex chromosomes and B chromosomes in the karyotype. About $45 \%$ of karyotypes in the database contain sex chromosomes, and $4 \%$ of the karyotypes harbor a variable number of $\mathrm{B}$ chromosomes. Considering the whole database, the rDNAs (45S and $5 \mathrm{~S}$ ) are located on autosomes $(88 \%)$, sex chromosomes $(11 \%)$, and B chromosomes $(1 \%)$. All mammals and birds carry sex chromosomes, whereas $2.5 \%$ of mollusks, $10.9 \%$ of fish, and $68.6 \%$ of arthropod karyotypes carry sex chromosomes.

Table 2 shows the frequency of sex chromosomes in individual groups and the occurrence of rDNA in them. Nearly all types of sex chromosomes may carry rDNA loci $(6.9 \% \mathrm{X}$, $2.5 \% \mathrm{Y}, 1 \% \mathrm{~W}$, and $0.6 \% \mathrm{Z}$ ). Among the heterogametic karyotypes, almost $33 \%$ of fish, $24 \%$ of arthropods, and $6 \%$ of mammals carried rDNA (5S or 45S) on sex chromosomes, suggesting a lower frequency of sex chromosome-linked rDNA in mammals compared to the other two groups (chi-square test, $p<0.001$, Table S5).

Table 2. Frequency of $5 \mathrm{~S}$ and $45 \mathrm{~S}$ rDNA localization on sex chromosomes.

\begin{tabular}{|c|c|c|c|c|c|c|c|c|c|c|c|}
\hline \multirow{3}{*}{ Group } & \multicolumn{3}{|c|}{ Karyotypes } & \multicolumn{4}{|c|}{ Karyotypes with $45 S$} & \multicolumn{4}{|c|}{ Karyotypes with 5S } \\
\hline & \multirow{2}{*}{$\begin{array}{c}\text { Total } \\
\mathbf{N t}\end{array}$} & \multicolumn{2}{|c|}{ with Sex chr. } & \multirow{2}{*}{$\begin{array}{c}\text { Total } \\
\mathbf{N}_{45}\end{array}$} & \multicolumn{3}{|c|}{$45 \mathrm{~S}$ on Sex chr. } & \multirow{2}{*}{$\begin{array}{c}\text { Total } \\
\mathrm{N}_{5}\end{array}$} & \multicolumn{3}{|c|}{$5 S$ on Sex chr. } \\
\hline & & $\mathbf{N}_{\text {sex }}$ & {$[\%]^{1}$} & & $\mathrm{~N}_{45 \operatorname{sex}}$ & {$[\%]^{2}$} & {$[\%]^{3}$} & & $\mathrm{~N}_{5 \text { sex }}$ & {$[\%]^{4}$} & {$[\%]^{5}$} \\
\hline Amphibians & 145 & 17 & 11.7 & 133 & 4 & 3 & 23.5 & 30 & 1 & 3.3 & 5.9 \\
\hline Arthropods & 1068 & 733 & 68.6 & 1057 & 153 & 14.5 & 20.9 & 112 & 38 & 33.9 & 5.2 \\
\hline Birds & 83 & 83 & 100 & 83 & 0 & 0 & 0 & 8 & 1 & 12.5 & 1.2 \\
\hline Fish & 953 & 104 & 10.9 & 892 & 29 & 3.3 & 27.9 & 800 & 14 & 1.8 & 13.5 \\
\hline Mammals & 275 & 275 & 100 & 263 & 14 & 5.3 & 5.1 & 44 & 5 & 11.4 & 1.8 \\
\hline Mollusks & 80 & 2 & 2.5 & 80 & 0 & 0 & 0 & 50 & 0 & 0 & 0 \\
\hline Reptiles & 175 & 70 & 40 & 175 & 7 & 4 & 10 & 13 & 0 & 0 & 0 \\
\hline
\end{tabular}

${ }^{1}$ Frequency of karyotypes with sex chromosomes calculated as: $100 \times \mathrm{N}_{\mathrm{sex}} / \mathrm{Nt} .{ }^{2}$ Frequency of karyotypes with $45 \mathrm{~S}$ rDNA on sex chromosomes calculated as: $100 \times \mathrm{N}_{45 \operatorname{sex}} / \mathrm{N}_{45} .{ }^{3}$ Proportion of karyotypes with sex chromosomes bearing $45 \mathrm{~S}$ rDNA loci on them: $100 \times \mathrm{N}_{45 \text { sex }} / \mathrm{N}_{\text {sex }} .{ }^{4}$ Frequency of karyotypes with $5 \mathrm{~S}$ rDNA on sex chromosomes calculated as: $100 \times \mathrm{N}_{5 \text { sex }} / \mathrm{N}_{5} .{ }^{5}$ Proportion of karyotypes with sex chromosomes bearing $5 \mathrm{~S}$ rDNA loci on them: $100 \times \mathrm{N}_{5 \text { sex }} / \mathrm{N}_{\text {sex }}$.

In addition, many other insect species only bear rDNA on sex chromosomes (option "sex chrom. number" on http://www.animalrdnadatabase.com/), and there are also examples of $45 \mathrm{~S}$ rDNA on both $\mathrm{X}$ and $\mathrm{Y}$ chromosomes in a single karyotype [42,43]. These observations support the hypothesis of the possible ancestral character of sex-linked NORs in insects as proposed in previous studies [15,29,44-47]. It is possible that there is selection towards a preferential position of NOR on sex chromosomes in insects. In support of this, the functionality of sex chromosome-linked NORs has been demonstrated by cytogenetic [48-50] and molecular methods [51]. NORs were also proposed to be involved in sex chromosome pairing and disjunction [30], and rDNA intergenic spacers might even participate in this process [52].

Next, we analyzed the mutual position of $5 \mathrm{~S}$ and $45 \mathrm{~S}$ rDNA on sex chromosomes. We selected karyotypes for which the positions of both loci are known (805 karyotypes) and where at least one of the loci (either $5 \mathrm{~S}$ or $45 \mathrm{~S}$ ) occurs on a sex chromosome (37 karyotypes). There are three possibilities: (i) $5 \mathrm{~S}$ rDNA is on a sex chromosome, and 45S rDNA is on an autosome; (ii) $5 \mathrm{~S}$ rDNA is on an autosome, and $45 \mathrm{~S}$ rDNA is on a sex chromosome; and (iii) both $5 \mathrm{~S}$ and $45 \mathrm{~S}$ rDNA are localized on sex chromosomes. The $5 \mathrm{~S}$ and $45 \mathrm{~S}$ loci may occur on the same [53] or different [54] sex chromosomes. However, the possibility of both 5S and $45 \mathrm{~S}$ rDNA in the same sex chromosome could not be evaluated due to the reduced species dataset with this feature. It is evident that karyotypes with both $5 \mathrm{~S}$ and $45 \mathrm{~S}$ on sex chromosomes were relatively frequent (Figure S1). Colocalization of $5 \mathrm{~S}$ and $45 \mathrm{~S}$ was also observed on an $\mathrm{M}$ chromosome in the insect Hypselonotus fulvus [55]. $\mathrm{M}$ chromosomes are believed to represent a transition state from autosome to sex chromosome, suggesting 
an autosomal origin of sex-linked chromosomes. Certainly, rDNA mobility could also be driven by transposons, which may spread rDNA from autosomes to sex chromosomes and vice versa $[56,57]$.

The frequency of rDNA on B chromosomes is shown in Table 3. Although the numbers are low due to the relatively low representation of species with $B$ chromosomes in the database, it is clear that the rDNA location of at least one locus ( $5 \mathrm{~S}$ or $45 \mathrm{~S}$ ) in B chromosomes is quite frequent in many of the amphibians, arthropods, fish, and mammals analyzed. Of note, in grasshoppers, rDNA on B chromosomes seems to be transcribed and form active nucleoli [58], so despite B chromosomes being seen as sometimes unnecessary or even harmful, it is also possible that they include important regulatory regions of the genome which might be under positive selection.

Table 3. Frequency of $5 S$ and $45 S$ rDNA localization on B chromosomes.

\begin{tabular}{|c|c|c|c|c|c|c|c|}
\hline \multirow[t]{2}{*}{ Group } & \multirow{2}{*}{$\frac{\text { Total }}{\mathbf{N}}$} & \multicolumn{3}{|c|}{$\begin{array}{l}\text { Species with } \\
\text { B chromosomes }\end{array}$} & \multicolumn{3}{|c|}{$\begin{array}{c}\text { Species with } 5 S \text { or } 45 S \text { rDNA on } \\
\text { B chromosomes }\end{array}$} \\
\hline & & $\mathbf{N}$ & {$[\%]$} & Range & $\mathbf{N}$ & {$[\%]$} & Fraction $[\%]^{1}$ \\
\hline Amphibians & 145 & 4 & 2.8 & $0-4$ & 1 & 0.7 & 25.0 \\
\hline Arthropods & 1068 & 56 & 5.2 & $0-14$ & 7 & 0.7 & 15.5 \\
\hline Fish & 953 & 34 & 3.6 & $0-10$ & 13 & 1.4 & 38.2 \\
\hline Flatworm & 14 & 1 & 7.1 & $0-4$ & 0 & 0.0 & 0 \\
\hline Mammals & 275 & 9 & 3.3 & $0-30$ & 2 & 0.7 & 22.2 \\
\hline Mollusks & 80 & 1 & 1.3 & $0-3$ & 0 & 0.0 & 0 \\
\hline Reptiles & 175 & 2 & 1.1 & $0-2$ & 0 & 0.0 & 0 \\
\hline
\end{tabular}

${ }^{1}$ Percentages are calculated as the number of species with rDNA on B chromosomes (column 6) divided by the number of species harboring B chromosomes (column 3).

In sum, the fact that rDNA on sex and B chromosomes is not an uncommon configuration raises a number of questions about the homogeneity of these particular chromosomes, which is supposed to be reduced compared to autosomes due to reduced meiotic recombination.

\subsection{Peculiarity of Bird and Reptile Karyotypes: Frequent Occurrence of rDNA on Microchromosomes}

The animal rDNA loci database also provides information on whether rDNAs occur in the distal, proximal, or interstitial position or on microchromosomes. These are very small chromosomes (usually less than $20 \mathrm{Mb}$ in size and less than $2.5 \mu \mathrm{m}$ long) found in all bird karyotypes, most reptiles, some fish, and rarely in other animals [59]. In our data sets, $100 \%$ of bird, $71 \%$ of reptile, and $4 \%$ of amphibian karyotypes contain microchromosomes (Table 4).

Table 4. Frequency of $45 \mathrm{~S}$ rDNA localization in microchromosomes.

\begin{tabular}{cccccccc}
\hline \multirow{2}{*}{ Group } & \multirow{2}{*}{ Total } & \multicolumn{2}{c}{ Species with Microchromosomes } & \multicolumn{2}{c}{ rDNA loci in Microchromosomes } \\
& & N & [\%] & Range (Median) & N & Fraction [\%] \\
\hline Amphibians & 145 & 6 & 4.1 & $6-50(36)$ & 4 & 2.8 & 66.7 \\
Birds & 83 & 83 & 100.0 & $6-72(62)$ & 71 & 85.5 & 35.5 \\
Lamprey & 3 & 3 & 100.0 & $164-168(168)$ & 3 & 0 & 100.0 \\
Fish & 953 & 6 & 0.6 & $3-44(20)$ & 0 & 0 & 20.2 \\
Reptiles & 175 & 125 & 71.4 & $2-50(22)$ & 35 & 28.0 \\
\hline
\end{tabular}

${ }^{1}$ Lampreys represent the most ancient lineage of modern vertebrates. Their chromosomes are typically numerous $(2 \mathrm{n}=144-188)$, and small $(0.5-5.0 \mu \mathrm{m})$ chromosomes are often regarded as microchromosomes [35]. Chromosome morphologies could be distinguished for some of them.

The localization of at least one $45 \mathrm{~S}$ rDNA site on microchromosomes was observed in $85.5 \%$ of birds (out of 83 karyotypes with microchromosomes), $27.8 \%$ of reptiles (out of 125 karyotypes with microchromosomes), and 66.7\% of amphibians (but only out of six karyotypes with microchromosomes). In contrast to other groups, most bird karyotypes did not display large variability in rDNA locus numbers, and 45S rDNA was typically located 
on a single pair of microchromosomes $[60,61]$, although significant exceptions exist even in this group. For example, peregrine falcons (Falco peregrinus) harbor $1645 \mathrm{~S}$ rDNA sites per diploid cell, all located on microchromosomes [62]. Interestingly, microchromosomes (11 pairs) are less abundant than the macrochromosomes (14 pairs) in the F. peregrinus karyotype $(2 n=50)$, underlining a relatively strong trend towards the preferential location of $45 \mathrm{~S}$ loci on microchromosomes. The $45 \mathrm{~S}$ rDNA is only exceptionally found on macrochromosomes, such as among birds of prey who belong to the subfamily Buteoninae [63]. This configuration is, however, believed to be a derived condition arising from chromosome rearrangements [26]. Birds are also distinct in having little or no karyotypic variability (most diploid counts range 74-86 [64]), resonating with the stasis of the rDNA loci in this group.

In contrast to birds, only $27.8 \%$ of reptile karyotypes show $45 \mathrm{~S}$ rDNA loci on microchromosomes. Crocodylidae are considered the evolutionary closest extant reptile family to birds, with both lineages separating c. 250 million years ago [65]. However, in Crocodylidae, $45 \mathrm{~S}$ rDNA is located on small chromosomes [66,67] that are not considered microchromosomes (Deakin and Ezaz 2019). However, more divergent groups less close to birds than crocodiles (such as snakes, lizards, and turtles) do present microchromosomes that carry rDNAs, albeit at a lower frequency than birds. Additionally, a considerable variation in NOR positions on macro- and microchromosomes was encountered at the genus level [68]. This suggests that rDNA localization in microchromosomes arose several times in the evolution of the reptile lineage. It is possible that there is a selection for the preferential position of $45 \mathrm{~S}$ rDNA in microchromosomes. These are usually highly GC rich [69], gene rich [70], and recombinationally active [71]. It is likely that 45S rDNA tends to amplify in chromosome niches with increased recombinogenic activity such as in the (sub)telomeric regions $[12,14]$ and microchromosomes.

As for $5 \mathrm{~S}$ rDNA in microchromosomes, the information is much more limited as compared to $45 \mathrm{~S}$ rDNA, although it has been identified in several birds [72,73], reptiles [66,74], and amphibians [75].

\subsection{Relationship between $45 \mathrm{~S}$ rDNA Locus Number and NOR Activity}

The rDNA expression is under epigenetic control, and only a subset of genes (and loci) are active in cells at a given time interval [76]. At the cytogenetic level, the activity of NORs has been studied by silver (Ag-NOR) staining in various systems and cell types [48,77-79]. The number of Ag-NOR signals is an important marker of cell proliferation in cancer biology [80]. Despite advances in understanding the molecular mechanisms of rDNA expression, cytogenetic information about the NOR activity is still valuable since the silencing of rDNA is a chromosome-specific epigenetic phenomenon [81]. The new database option "Ag-NOR" returns information about the number of active NORs in karyotypes. This is based on the silver nitrate staining of the nucleolar organization region (NOR)-associated proteins, producing a dark region wherein the silver is deposited, and denoting the activity of rRNA genes within the NOR [82]. The database contains information about the number of Ag-NOR signals in 1192 karyotypes, which is almost half of its total content. Most data come from fish (606 karyotypes) and arthropods (300); the rest comprise diverse groups including mammals, birds, and reptiles.

We analyzed the relationship between the number of $45 \mathrm{~S}$ rDNA sites and the number of Ag-NOR signals (Figure 3D). As expected, there was a positive correlation between both variables (Spearman's test, $p<0.05$ (Table S4)). We also analyzed the number of Ag-NORs in groups differing in number of loci (Figure 4).

In a group with two rDNA sites per diploid (corresponding to median number), the number of Ag-NOR signals roughly corresponds to the number of loci. However, as the number of loci increases, the relative proportion of Ag-NOR signals decreases. These results are correlated with those obtained at the genus level and involving smaller data sets. For example, in grasshoppers with a relatively high number of rDNA loci and genes [19], the number of inactive loci (Ag-NOR negative) ranged 12.7-22\% [83]. Thus, 
despite a positive correlation between the number of $45 \mathrm{~S}$ loci and number of Ag-NOR signals, the relationship is not a linear one. Karyotypes with a low and intermediate number of loci frequently show nearly all rDNA loci as active, whereas only less than half of them are usually active in karyotypes with a high number of loci.

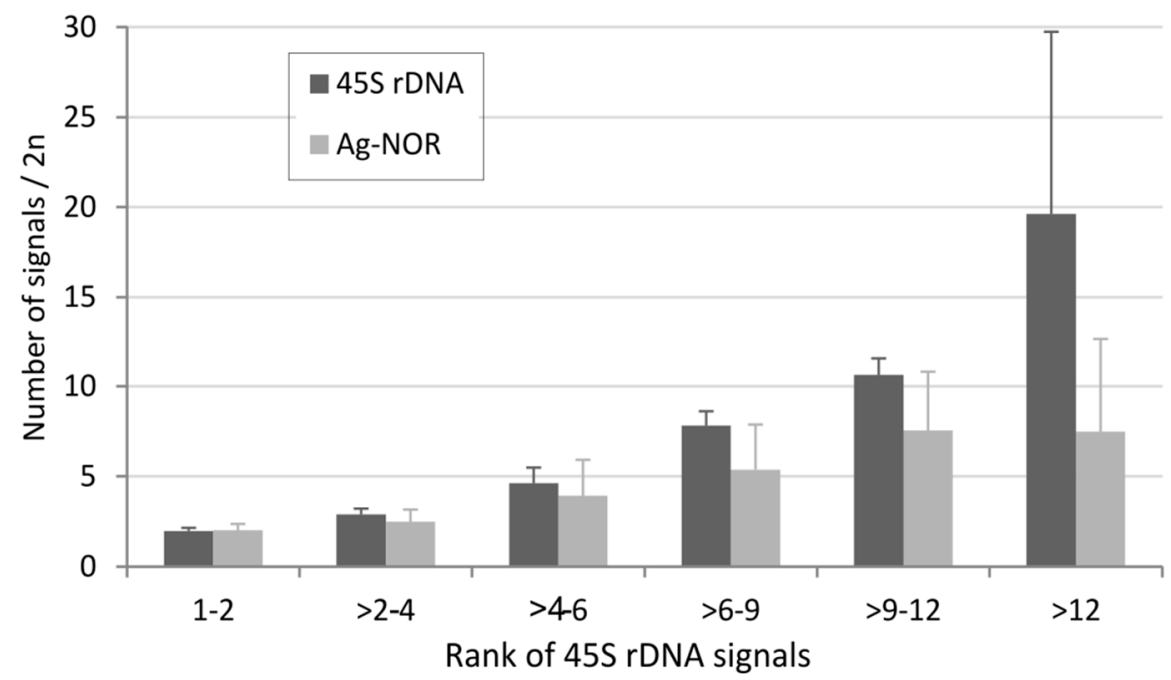

Figure 4. Relationship between the number of $45 \mathrm{~S}$ rDNA loci and the number of Ag-NOR signals. The average number of Ag-NOR signals and loci was counted in each group differing in locus number (x-axis) and expressed as an average (y-axis). The number of karyotypes in each group was as follows: 753 (group "1-2"), 60 (">2-4"), 237 (">4-6"), 44 ("6-9"), 32 (">9-12"), and 31 ("> 12 ").

\section{Conclusions}

The updated version of the animal rDNA loci database (http: / / www.animalrdnadatabase. $\mathrm{com} /$ ) presents a source of information about rDNA loci in a wide range of animal genera. Its new options allow the retrieval of information about the expression activity of rDNA loci and their position on different chromosome types. The animal rDNA loci database is a part of a long-term project also involving a mirror plant rDNA loci database (http:/ /www.plantrdnadatabase.com/). We hope these regularly updated resources will be useful for evolutionary and structural analyses. Considering that the database's coverage of information about the number and position of rDNA loci in chromosomes is still fragmentary (less than $0.2 \%$ species), to ensure that such comparative analyses are robust, there is clearly an ongoing need for high-quality cytogenetic studies, particularly in less represented groups, to make the data more comprehensive of animal diversity as a whole.

Supplementary Materials: The following files are available online at https://www.mdpi.com/ article/10.3390/ijms222111403/s1. Table S1: Statistical evaluation of the number of 5S and 45S rDNA loci in karyotypes. Table S2: Statistical comparison of the $5 \mathrm{~S}$ and $45 \mathrm{~S}$ average locus numbers using Mann-Whitney and ANOVA one-way tests. Page $1-45$ S rDNA analyses. Page 2-5S rDNA analyses. Table S3: Statistical evaluation of rDNA loci variability between the groups (Levene's test, [24]). Table S4: Correlations between the rDNA locus numbers and other variables including number of chromosomes and number of Ag-NOR signals. Table S5: Comparison of the frequency of $45 \mathrm{~S}$ rDNA loci on sex chromosomes between the main groups of animals (chi-square test). Table S5: Statistical evaluation of the $45 \mathrm{~S}$ rDNA locus numbers and number of Ag-NOR signals between the groups. Figure S1. Venn diagram showing the proportion of $45 \mathrm{~S}$ and $5 \mathrm{~S}$ loci on sex chromosomes in karyotypes with known positions for both loci and where either $5 \mathrm{~S}$ or $45 \mathrm{~S}$ occur on a sex chromosome. $\mathrm{N}$ is the number of species.

Author Contributions: Conceptualization, A.K., J.S., and S.G.; investigation, A.K., F.G., J.S. and R.M.; validation, F.G., J.S. and R.M.; writing — original draft preparation, A.K. and J.S.; writing—review and editing, F.G., J.S., S.G. and R.M. All authors have read and agreed to the published version of the manuscript. 
Funding: The work was supported by the Czech Science Foundation (19-03442S and 20-28029S) and PPLZ program (L200041951).

Institutional Review Board Statement: The study was conducted according to the guidelines of the Declaration of Helsinki and in agreement with the Code of Ethics for Researchers of the Czech Academy of Sciences: https:/ / www.avcr.cz/en/about-us/legal-regulations/code-of-ethics-forresearchers-of-the-czech-academy-of-sciences. (Institute of Biophysics ASCR, Act No. 283/1992 Coll.). The study did not involve humans or animals.

Informed Consent Statement: All subjects gave their informed consent for inclusion before they participated in the study. The work was carried out in agreement with the Code of Ethics for Researchers by the Czech Academy of Sciences: https:/ / www.avcr.cz/en/about-us/legal-regulations / code-of-ethics-for-researchers-of-the-czech-academy-of-sciences.

Data Availability Statement: All data regarding results are available in the supplementary information and online at http://www.animalrdnadatabase.com/.

Acknowledgments: We thank all authors of the original publications whose data contributed to the animal rDNA loci database.

Conflicts of Interest: The authors declare no conflict of interest.

\section{References}

1. Symonova, R. Integrative rDNAomics-Importance of the Oldest Repetitive Fraction of the Eukaryote Genome. Genes 2019, 10, 345. [CrossRef]

2. Bersaglieri, C.; Santoro, R. Genome Organization in and around the Nucleolus. Cells 2019, 8, 579. [CrossRef]

3. Kobayashi, T. A new role of the rDNA and nucleolus in the nucleus-rDNA instability maintains genome integrity. Bioessays 2008, 30, 267-272. [CrossRef]

4. McClintock, B. The relationship of a particular chromosomal element to the development of the nucleoli in Zea mays. Zeitschrift für Zellforschung und mikroskopische Anatomie 1934, 21, 294-398. [CrossRef]

5. Gall, J.G. Chromosome structure and the C-value paradox. J. Cell Biol. 1981, 91, 3s-14s. [CrossRef]

6. Baumlein, H.; Wobus, U. Chromosomal Localization of Ribosomal 5S Rna Genes in Chironomus-Thumni by in Situ Hybridization of Iodinated 5s Rna. Chromosoma 1976, 57, 199-204. [CrossRef] [PubMed]

7. Schweizer, D.; Mendelak, M.; White, M.J.D.; Contreras, N. Cytogenetics of the parthenogenetic grasshopper Warramaba virgo and its bisexual relatives. Chromosoma 1983, 88, 227-236. [CrossRef]

8. Bauman, J.G.J.; Wiegant, J.; Borst, P.; Vanduijn, P. A New Method for Fluorescence Microscopical Localization of Specific DNA-Sequences by Insitu Hybridization of Fluorochrome-Labeled Rna. Exp. Cell Res. 1980, 128, 485-490. [CrossRef]

9. Cabral-de-Mello, D.C.; Marec, F. Universal fluorescence in situ hybridization (FISH) protocol for mapping repetitive DNAs in insects and other arthropods. Mol. Genet. Genom. 2021, 296, 513-526. [CrossRef]

10. Alves-Silva, A.P.; Barros, L.A.C.; das Graças Pompolo, S. General Protocol of FISH for Insects. In Fluorescence In Situ Hybridization (FISH): Application Guide; Liehr, T., Ed.; Springer: Berlin/Heidelberg, Germany, 2017; pp. 459-466.

11. Yano, C.F.; Bertollo, L.A.C.; de Bello Cioffi, M. Fish-FISH: Molecular Cytogenetics in Fish Species. In Fluorescence In Situ Hybridization (FISH): Application Guide; Liehr, T., Ed.; Springer: Berlin/Heidelberg, Germany, 2017; pp. $429-443$.

12. Garcia, S.; Kovarik, A.; Leitch, A.R.; Garnatje, T. Cytogenetic features of rRNA genes across land plants: Analysis of the Plant rDNA database. Plant J. 2017, 89, 1020-1030. [CrossRef] [PubMed]

13. Sochorova, J.; Garcia, S.; Galvez, F.; Symonova, R.; Kovarik, A. Evolutionary trends in animal ribosomal DNA loci: Introduction to a new online database. Chromosoma 2018, 127, 141-150. [CrossRef] [PubMed]

14. Roa, F.; Guerra, M. Non-Random Distribution of 5S rDNA Sites and Its Association with 45S rDNA in Plant Chromosomes. Cytogenet. Genome Res. 2015, 146, 243-249. [CrossRef] [PubMed]

15. Drosopoulou, E.; Nakou, I.; Sichova, J.; Kubickova, S.; Marec, F.; Mavragani-Tsipidou, P. Sex chromosomes and associated rDNA form a heterochromatic network in the polytene nuclei of Bactrocera oleae (Diptera: Tephritidae). Genetica 2012, 140, 169-180. [CrossRef] [PubMed]

16. Bombarova, M.; Marec, F.; Nguyen, P.; Spakulova, M. Divergent location of ribosomal genes in chromosomes of fish thorny-headed worms, Pomphorhynchus laevis and Pomphorhynchus tereticollis (Acanthocephala). Genetica 2007, 131, 141-149. [CrossRef]

17. Marques, A.; Klemme, S.; Houben, A. Evolution of Plant B Chromosome Enriched Sequences. Genes 2018, 9, 515. [CrossRef]

18. Utsunomia, R.; Silva, D.M.; Ruiz-Ruano, F.J.; Araya-Jaime, C.; Pansonato-Alves, J.C.; Scacchetti, P.C.; Hashimoto, D.T.; Oliveira, C.; Trifonov, V.A.; Porto-Foresti, F.; et al. Uncovering the Ancestry of B Chromosomes in Moenkhausia sanctaefilomenae (Teleostei, Characidae). PLoS ONE 2016, 11, e0150573. [CrossRef]

19. Keller, I.; Chintauan-Marquier, I.C.; Veltsos, P.; Nichols, R.A. Ribosomal DNA in the grasshopper Podisma pedestris: Escape from concerted evolution. Genetics 2006, 174, 863-874. [CrossRef] 
20. Wang, W.C.; Ma, L.; Becher, H.; Garcia, S.; Kovarikova, A.; Leitch, I.J.; Leitch, A.R.; Kovarik, A. Astonishing 35S rDNA diversity in the gymnosperm species Cycas revoluta Thunb. Chromosoma 2016, 125, 683-699. [CrossRef]

21. Garcia, S.; Garnatje, T.; Kovarik, A. Plant rDNA database: Ribosomal DNA loci information goes online. Chromosoma 2012, 121, 389-394. [CrossRef]

22. RStudio Team. RStudio: Integrated Development Environment for R; RStudio, PBC: Boston, MA, USA, 2021. Available online: http:/ / www.rstudio.com/ (accessed on 2 May 2021).

23. Mann Whitney U Test Calculator. Statistics Kingdom. 2017. Available online: http://www.statskingdom.com/170median_ mann_whitney.html (accessed on 10 September 2021).

24. Levene's Test. Statistics Kingdom. 2017. Available online: https://www.statskingdom.com/230var_levenes.html (accessed on 10 September 2021).

25. IUCN The IUCN Red List of Threatened Species. Version 2021-2. Available online: https://www.iucnredlist.org (accessed on 1 June 2021).

26. Degrandi, T.M.; Gunski, R.J.; Garnero, A.D.; de Oliveira, E.H.C.; Kretschmer, R.; de Souza, M.S.; Barcellos, S.A.; Hass, I. The distribution of $45 \mathrm{~S}$ rDNA sites in bird chromosomes suggests multiple evolutionary histories. Genet. Mol. Biol. 2020, 43. [CrossRef]

27. Zhang, Z.Q. Phylum Arthropoda. Zootaxa 2013, 3703, 17-26. [CrossRef]

28. Stahlavsky, F.; Nguyen, P.; Sadilek, D.; Stundlova, J.; Just, P.; Haddad, C.R.; Koc, H.; Ranawana, K.B.; Stockmann, M.; Yagmur, E.A.; et al. Evolutionary dynamics of rDNA clusters on chromosomes of buthid scorpions (Chelicerata: Arachnida). Biol. J. Linn. Soc. 2020, 131, 547-565. [CrossRef]

29. Sichova, J.; Nguyen, P.; Dalikova, M.; Marec, F. Chromosomal evolution in Tortricid moths: Conserved karyotypes with diverged features. PLoS ONE 2013, 8, e64520. [CrossRef] [PubMed]

30. Roy, V.; Monti-Dedieu, L.; Chaminade, N.; Siljak-Yakovlev, S.; Aulard, S.; Lemeunier, F.; Montchamp-Moreau, C. Evolution of the chromosomal location of rDNA genes in two Drosophila species subgroups: Ananassae and melanogaster. Heredity 2005, 94, 388-395. [CrossRef]

31. Cabral-de-Mello, D.C.; Cabrero, J.; Lopez-Leon, M.D.; Camacho, J.P.M. Evolutionary dynamics of 5S rDNA location in acridid grasshoppers and its relationship with $\mathrm{H} 3$ histone gene and 45S rDNA location. Genetica 2011, 139, 921-931. [CrossRef] [PubMed]

32. Cazaux, B.; Catalan, J.; Veyrunes, F.; Douzery, E.J.P.; Britton-Davidian, J. Are ribosomal DNA clusters rearrangement hotspots? A case study in the genus Mus (Rodentia, Muridae). BMC Evol. Biol. 2011, 11, 124. [CrossRef] [PubMed]

33. Rebordinos, L.; Cross, I.; Merlo, A. High evolutionary dynamism in 5S rDNA of fish: State of the art. Cytogenet. Genome Res. 2013, 141, 103-113. [CrossRef] [PubMed]

34. Roa, F.; Guerra, M. Distribution of $45 \mathrm{~S}$ rDNA sites in chromosomes of plants: Structural and evolutionary implications. BMC Evol. Biol. 2012, 12, 225. [CrossRef] [PubMed]

35. Ishijima, J.; Uno, Y.; Nunome, M.; Nishida, C.; Kuraku, S.; Matsuda, Y. Molecular cytogenetic characterization of chromosome site-specific repetitive sequences in the Arctic lamprey (Lethenteron camtschaticum, Petromyzontidae). DNA Res. 2017, 24, 93-101. [CrossRef]

36. Covelo-Soto, L.; Moran, P.; Pasantes, J.J.; Perez-Garcia, C. Cytogenetic evidences of genome rearrangement and differential epigenetic chromatin modification in the sea lamprey (Petromyzon marinus). Genetica 2014, 142, 545-554. [CrossRef]

37. Caputo, V.; Giovannotti, M.; Cerioni, P.N.; Splendiani, A.; Tagliavini, J.; Olmo, E. Chromosomal study of a lamprey (Lampetra zanandreai Vladykov, 1955) (Petromyzonida: Petromyzontiformes): Conventional and FISH analysis. Chromosome Res. 2011, 19, 481-491. [CrossRef]

38. Mlinarec, J.; Muzic, M.; Pavlica, M.; Srut, M.; Klobucar, G.; Maguire, I. Comparative karyotype investigations in the European crayfish Astacus astacus and A. leptodactylus (Decapoda, Astacidae). Crustaceana 2011, 84, 1497-1510.

39. Fontana, F.; Lanfredi, M.; Congiu, L.; Leis, M.; Chicca, M.; Rossi, R. Chromosomal mapping of 18S-28S and 5S rRNA genes by two-colour fluorescent in situ hybridization in six sturgeon species. Genome 2003, 46, 473-477. [CrossRef]

40. Hall, A.N.; Turner, T.N.; Queitsch, C. Thousands of high-quality sequencing samples fail to show meaningful correlation between $5 S$ and 45 ribosomal DNA arrays in humans. Sci. Rep. 2021, 11, 449. [CrossRef]

41. Gibbons, J.G.; Branco, A.T.; Godinho, S.A.; Yu, S.; Lemos, B. Concerted copy number variation balances ribosomal DNA dosage in human and mouse genomes. Proc. Natl. Acad. Sci. USA 2015, 112, 2485-2490. [CrossRef] [PubMed]

42. Panzera, F.; Pita, S.; Nattero, J.; Panzera, Y.; Galvao, C.; Chavez, T.; De Arias, A.R.; Tellez, L.C.; Noireau, F. Cryptic speciation in the Triatoma sordida subcomplex (Hemiptera, Reduviidae) revealed by chromosomal markers. Parasite Vector 2015, 8, 495. [CrossRef] [PubMed]

43. Hennig, W.; Link, B.; Leoncini, O. Location of Nucleolus Organizer Regions in Drosophila-Hydei. Chromosoma 1975, 51, 57-63. [CrossRef]

44. Marchi, A.G.; Messi, G.; Renier, S.; Gallone, G.; Peisino, M.G.; Viettiramus, M.; Raspino, M.; Chiossi, M.; Lattere, M.; Polla, D. The risk associated with poisonings in children. Vet. Hum. Toxicol. 1994, 36, 112-116. [PubMed]

45. Brianti, M.T.; Ananina, G.; Recco-Pimentel, S.M.; Klaczko, L.B. Comparative analysis of the chromosomal positions of rDNA genes in species of the tripunctata radiation of Drosophila. Cytogenet. Genome Res. 2009, 125, 149-157.

46. Kuznetsova, V.G.; Khabiev, G.N.; Anokhin, B.A. Cytogenetic study on antlions (Neuroptera, Myrmeleontidae): First data on telomere structure and rDNA location. Comp. Cytogenet. 2016, 10, 647-656. [CrossRef] 
47. Lohe, A.R.; Roberts, P.A. Evolution of DNA in heterochromatin: The Drosophila melanogaster sibling species subgroup as a resource. Genetica 2000, 109, 125-130. [CrossRef]

48. Stitou, S.; Burgos, M.; Zurita, F.; Jimenez, R.; Sanchez, A.; Diaz de la Guardia, R. Recent evolution of NOR-bearing and sex chromosomes of the North African rodent Lemniscomys barbarus. Chromosome Res. 1997, 5, 481-485. [CrossRef]

49. Maffei, E.M.D.; Pompolo, S.D.G.; Campos, L.A.D.; Petitpierre, E. Sequential FISH analysis with rDNA genes and Ag-NOR banding in the lady beetle Olla v-nigrum (Coleoptera: Coccinellidae). Hereditas 2001, 135, 13-18. [CrossRef]

50. Raudsepp, T. Cytogenetics and Infertility. In Llama and Alpaca Care; Cebra, C., Anderson, D.E., Tibary, A., Van Saun, R.J., Johnson, L.W., Eds.; W.B. Saunders: St. Louis, MO, USA, 2014; Chapter 21; pp. 243-249.

51. Paredes, S.; Branco, A.T.; Hartl, D.L.; Maggert, K.A.; Lemos, B. Ribosomal DNA deletions modulate genome-wide gene expression: "rDNA-sensitive" genes and natural variation. PLoS Genet. 2011, 7, e1001376. [CrossRef]

52. Nguyen, P.; Sahara, K.; Yoshido, A.; Marec, F. Evolutionary dynamics of rDNA clusters on chromosomes of moths and butterflies (Lepidoptera). Genetica 2010, 138, 343-354. [CrossRef]

53. Bizzaro, D.; Mandrioli, M.; Zanotti, M.; Giusti, M.; Manicardi, G.C. Chromosome analysis and molecular characterization of highly repeated DNAs in the aphid Acyrthosiphon pisum (Aphididae, Hemiptera). Genetica 2000, 108, 197-202. [CrossRef]

54. Blanco, D.R.; Vicari, M.R.; Lui, R.L.; Artoni, R.F.; de Almeida, M.C.; Traldi, J.B.; Margarido, V.P.; Moreira, O. Origin of the $\mathrm{X}_{1} \mathrm{X}_{1} \mathrm{X}_{2} \mathrm{X}_{2} / \mathrm{X}_{1} \mathrm{X}_{2} \mathrm{Y}$ sex chromosome system of Harttia punctata (Siluriformes, Loricariidae) inferred from chromosome painting and FISH with ribosomal DNA markers. Genetica 2014, 142, 119-126. [CrossRef] [PubMed]

55. Bardella, V.B.; Fernandes, J.A.M.; Cabral-de-Mello, D.C. Chromosomal evolutionary dynamics of four multigene families in Coreidae and Pentatomidae (Heteroptera) true bugs. Mol. Genet. Genom. 2016, 291, 1919-1925. [CrossRef] [PubMed]

56. Symonova, R.; Majtanova, Z.; Sember, A.; Staaks, G.B.O.; Bohlen, J.; Freyhof, J.; Rabova, M.; Rab, P. Genome differentiation in a species pair of coregonine fishes: An extremely rapid speciation driven by stress-activated retrotransposons mediating extensive ribosomal DNA multiplications. BMC Evol. Biol. 2013, 13, 42. [CrossRef] [PubMed]

57. Raskina, O.; Belyayev, A.; Nevo, E. Activity of the En/Spm-like transposons in meiosis as a base for chromosome repatterning in a small, isolated, peripheral population of Aegilops speltoides Tausch. Chromosome Res. 2004, 12, 153-161. [CrossRef] [PubMed]

58. Ruiz-Estevez, M.; Lopez-Leon, M.D.; Cabrero, J.; Camacho, J.P.M. B-Chromosome ribosomal DNA is functional in the grasshopper Eyprepocnemis plorans. PLoS ONE 2012, 7, e36600. [CrossRef] [PubMed]

59. Ezaz, T.; Young, M. Microchromosomes. In Brenner's Encyclopedia of Genetics, 2nd ed.; Maloy, S., Hughes, K., Eds.; Academic Press: San Diego, CA, USA, 2013; pp. 405-407.

60. Griffin, D.K.; Robertson, L.B.W.; Tempest, H.G.; Skinner, B.M. The evolution of the avian genome as revealed by comparative molecular cytogenetics. Cytogenet. Genome Res. 2007, 117, 64-77.

61. Dyomin, A.G.; Koshel, E.I.; Kiselev, A.M.; Saifitdinova, A.F.; Galkina, S.A.; Fukagawa, T.; Kostareva, A.A.; Gaginskaya, E.R. Chicken rRNA Gene Cluster Structure. PLoS ONE 2016, 11, e0157464. [CrossRef]

62. Nishida, C.; Ishijima, J.; Kosaka, A.; Tanabe, H.; Habermann, F.A.; Griffin, D.K.; Matsuda, Y. Characterization of chromosome structures of Falconinae (Falconidae, Falconiformes, Aves) by chromosome painting and delineation of chromosome rearrangements during their differentiation. Chromosome Res. 2008, 16, 171-181. [CrossRef]

63. de Oliveira, E.H.C.; Tagliarini, M.M.; dos Santos, M.S.; O’Brien, P.C.M.; Ferguson-Smith, M.A. Chromosome Painting in Three Species of Buteoninae: A Cytogenetic Signature Reinforces the Monophyly of South American Species. PLoS ONE 2013, 8, e70071. [CrossRef]

64. Degrandi, T.M.; Barcellos, S.A.; Costa, A.L.; Garnero, A.D.V.; Hass, I.; Gunski, R.J. Introducing the Bird Chromosome Database: An overview of cytogenetic studies in birds. Cytogenet. Genome Res. 2020, 160, 199-205. [CrossRef]

65. Green, R.E.; Braun, E.L.; Armstrong, J.; Earl, D.; Nguyen, N.; Hickey, G.; Vandewege, M.W.; St John, J.A.; Capella-Gutiérrez, S.; Castoe, T.A.; et al. Three crocodilian genomes reveal ancestral patterns of evolution among archosaurs. Science 2014, 346, 1254449. [CrossRef]

66. Kawagoshi, T.; Nishida, C.; Ota, H.; Kumazawa, Y.; Endo, H.; Matsuda, Y. Molecular structures of centromeric heterochromatin and karyotypic evolution in the Siamese crocodile (Crocodylus siamensis) (Crocodylidae, Crocodylia). Chromosome Res. 2008, 16, 1119-1132. [CrossRef] [PubMed]

67. King, M.; Honeycutt, R.; Contreras, N. Chromosomal repatterning in crocodiles: C, G and N-banding and the in situ hybridization of 18S and 26S rRNA cistrons. Genetica 1986, 70, 191-201. [CrossRef]

68. Porter, C.A.; Haiduk, M.W.; Dequeiroz, K. Evolution and phylogenetic significance of ribosomal gene location in chromosomes of squamate reptiles. Copeia 1994, 1994, 302-313. [CrossRef]

69. Andreozzi, L.; Federico, C.; Motta, S.; Saccone, S.; Sazanova, A.L.; Sazanov, A.A.; Smirnov, A.F.; Galkina, S.A.; Lukina, N.A.; Rodionov, A.V.; et al. Compositional mapping of chicken chromosomes and identification of the gene-richest regions. Chromosome Res. 2001, 9, 521-532. [CrossRef]

70. Smith, J.; Bruley, C.K.; Paton, I.R.; Dunn, I.; Jones, C.T.; Windsor, D.; Morrice, D.R.; Law, A.S.; Masabanda, J.; Sazanov, A.; et al. Differences in gene density on chicken macrochromosomes and microchromosomes. Anim. Genet. 2000, 31, 96-103. [CrossRef]

71. Burt, D.W. Origin and evolution of avian microchromosomes. Cytogenet. Genome Res. 2002, 96, 97-112.

72. Gunski, R.J.; Kretschmer, R.; de Souza, M.S.; Furo, I.D.; Barcellos, S.A.; Costa, A.L.; Cioffi, M.B.; de Oliveira, E.H.C.; Garnero, A.D. Evolution of Bird Sex Chromosomes Narrated by Repetitive Sequences: Unusual W Chromosome Enlargement in Gallinula melanops (Aves: Gruiformes: Rallidae). Cytogenet. Genome Res. 2019, 158, 152-159. [CrossRef] 
73. dos Santos, M.D.; Kretschmer, R.; Silva, F.A.O.; Ledesma, M.A.; O’Brien, P.C.M.; Ferguson-Smith, M.A.; Garnero, A.D.; de Oliveira, E.H.C.; Gunski, R.J. Intrachromosomal rearrangements in two representatives of the genus Saltator (Thraupidae, Passeriformes) and the occurrence of heteromorphic Z chromosomes. Genetica 2015, 143, 535-543. [CrossRef] [PubMed]

74. Cavalcante, M.G.; Nagamachi, C.Y.; Pieczarka, J.C.; Noronha, R.C.R. Evolutionary insights in Amazonian turtles (Testudines, Podocnemididae): Co-location of 5S rDNA and U2 snRNA and wide distribution of Tc1/Mariner. Biol. Open 2020, 9, bio049817. [CrossRef] [PubMed]

75. Vitelli, L.; Batistoni, R.; Andronico, F.; Nardi, I.; Barsacchi-Pilone, G. Chromosomal localization of 18S + 28S and 5S Ribosomal RNA genes in evolutionarily diverse anuran amphibians. Chromosoma 1982, 84, 475-491. [CrossRef] [PubMed]

76. Grummt, I.; Pikaard, C.S. Epigenetic silencing of RNA polymerase I transcription. Nat. Rev. Mol. Cell Biol. 2003, 4, 641-649. [CrossRef]

77. Barth, A.; Souza, V.A.; Sole, M.; Costa, M.A. Molecular cytogenetics of nucleolar organizer regions in Phyllomedusa and Phasmahyla species (Hylidae, Phyllomedusinae): A cytotaxonomic contribution. Genet. Mol. Res. 2013, 12, 2400-2408. [CrossRef]

78. Goodpasture, C.; Bloom, S.E. Visualization of nucleolar organizer regions im mammalian chromosomes using silver staining. Chromosoma 1975, 53, 37-50. [CrossRef]

79. Moreno, F.J.; Rodrigo, R.M.; Garcia-Herdugo, G. Ag-NOR proteins and rDNA transcriptional activity in plant cells. J. Histochem. Cytochem. 1990, 38, 1879-1887. [CrossRef] [PubMed]

80. Plate, K.H.; Ruschoff, J.; Mennel, H.D. Application of the AgNOR technique to neurooncology. Acta Histochem. Suppl. 1992, 42, 171-178.

81. Mohannath, G.; Pontvianne, F.; Pikaard, C.S. Selective nucleolus organizer inactivation in Arabidopsis is a chromosome positioneffect phenomenon. Proc. Natl. Acad. Sci. USA 2016, 113, 13426-13431. [CrossRef]

82. Trerè, D. AgNOR staining and quantification. Micron 2000, 31, 127-131. [CrossRef]

83. Cabrero, J.; Camacho, J.P.M. Location and expression of ribosomal RNA genes in grasshoppers: Abundance of silent and cryptic loci. Chromosome Res. 2008, 16, 595-607. [CrossRef] 